\title{
Nutrient content, Sensory and Storage Stability of Meat floss Incorporated with Cassava leaves
}

\author{
Aishah Bujang ${ }^{12}$, Siti Sarah Jamil ${ }^{2}$, Noor Farahin Basar ${ }^{2}$, Norfezah Md Nor ${ }^{3}$ \\ ${ }^{I}$ Malaysia Institute of Transport (MITRANS), Universiti Teknologi MARA, Shah Alam, 40450 Selangor, \\ Malaysia \\ ${ }^{2}$ Faculty of Applied Sciences, Universiti Teknologi MARA, Shah Alam, 40450 Selangor, Malaysia. \\ ${ }^{3}$ Faculty of Hotel and Tourism, Universiti Teknologi MARA Pulau Pinang, 13500 Jalan Permatang Pauh, Pulau \\ Pinang, Malaysia.
}

\begin{abstract}
A lot of effort is needed to diverse food products utilisation of cassava leaves which are regarded as famine reserve crop for food security. The objective of this study was to evaluate protein, fibre and sensory of meat floss incorporated with different amount of cassava leaves $(C L)(25 \%, 50 \%, 75 \%$ and $100 \%)$. Its stability during storage was monitored for 84 days in terms of lipid oxidation through peroxide value (PV) and formation of thiobarbituric acid reactive substance (TBARS). The results showed that protein content decreases while fibre content increases with the increase amount of CL substitution. No significant difference ( $p>0.05)$ was obtained in preference based on sensory attributes of texture, taste and overall acceptability of control floss with 100\% CL substituted floss. At initial storage duration (up to day 30), similar linear increase in PV was observed among all formulations; however, further storage showed slower increment by the $100 \%$ CL substituted floss. Similarly, faster formation of TBARS was shown by control floss while the lowest values was shown by 100\% CL floss. This study showed that CL is a suitable alternative for meat and also proved that total substitution of $C L$ was well accepted and has longer storage stability compared to meat floss.
\end{abstract}

Keywords: cassava leaf, fiber, lipid oxidation, meat floss, protein

\section{Introduction}

Cassava leaves are considered as one of the food securities for green vegetables that could help in providing important nutrients such as protein, and vitamins and minerals for the undernourished and malnourished people. It has great potential in helping 870 million hungry people of the world [1] in addition to 3 billion people who have insufficient amount of vitamins and minerals [2]. This is because cassava leaves contain significant amount of crude protein (17.7 to $38.1 \%$ dry matter basis) [3] and vitamins such as B1, B2, C, and carotenoids [4]. Total essential amino acids in cassava leaf protein is comparable to egg and exceeded the amount found in spinach leaves, soybean, oat and rice grain [5]. The high protein content of cassava leaves thus makes them a good protein source from plant origin, alternative to the protein from animal source. High contents of minerals like phosphorus, magnesium, potassium and calcium with low contents of manganese, zinc, copper, iron and sodium were reported in cassava leaves depending on leaf maturity, cultivar and climatic conditions [6], [7], [8]. Crude fibre content from cassava leaves ranges from $8.3 \mathrm{~g} / 100 \mathrm{~g}$ in very young leaves to $27.4 \mathrm{~g} / 100 \mathrm{~g}$ in mature leaves, as reported by [6]. Vitamin C content of 231 and $482 \mathrm{mg} / 100 \mathrm{~g}$ were found in light and dark-colored fresh leaves respectively for Malaysian cassava cultivars, whereas Ghanaian cultivars were found to have higher content of $742 \mathrm{mg} / 100 \mathrm{~g}$ [8]. Due to their high micronutrients content, cassava leaves have been made into a powder form to serve as a food supplement to combat malnutrition in Brazil [9]. The consumption of cassava leaves by pregnant women is also practiced in Sierra Leone and Liberia to increase breast milk production [10].

Cassava (Manihot esculenta Crantz) plant is grown in 105 tropical and subtropical countries of Latin America, Africa and Asia. In 2020, this world's fourth important crop cultivation [11] is estimated to increase to 291 million tons [12]. The cassava plant is most commonly used for its starchy tubers; its leaves are regarded as a by-product which is still underutilized and its diversification as food product is therefore needed. Cassava plant is not a seasonal crop - it is available throughout the year and this scrubby plant is able to tolerate drought and acidic or infertile soils [13]; thus, making it an important famine reserved crop. In many African countries, cassava tubers and leaves are a staple food which constitute as major component of their diet. However, in Asian countries such as Malaysia, Indonesia and Philippines, cassava cultivation in large scale plantation is mainly after its flour or starch production from the tubers as well as production of monosodium glutamate, while limited amount of the leaves is used as animal feed. In Malaysia, smaller plantation usually supplies the tubers to small and medium sized industries for chips and snacks production. A small amount of the leaves are consumed as vegetable cooked in local traditional cuisines or simply eaten with rice after boiling as "ulam". 
Knowing the importance of cassava in food security and its potential as an economic source of income, scientists have created improved cassava varieties in order to enhance its nutritional values through genomics and molecular biology techniques [13]. In Malaysia, about 80 varieties of cassava plant are being developed using tissue culture method by the Malaysian Agricultural Research and Development (MARDI) [14]. It is time to focus our attention to cassava leaves as a source of protein and nutrients for human nutrition as well as encourage their valuable addition in the diet. Greater utilisation and exploitation of the leaves through product innovation and invention of new cassava leaves based food products should be promoted. This study was conducted as an effort to innovate the current meat floss product or locally known as "serunding" in Malaysia as well as to diversify utilisation of cassava leaves. The objective of this study was to evaluate the protein and fiber content of meat floss incorporated with cassava leaves and consumer acceptability of the innovated product. The product stability in terms of lipid oxidation progress was also monitored during storage.

\subsection{Procurements of raw material}

\section{Material and Methods}

Fresh cassava leaves of "Putih" variety was obtained from MARDI, Serdang, Selangor, Malaysia. Leaves from the top to lower 5 tiers were used in the study. Beef meat, coconut milk, oil, onion, garlic, ginger, galangal dried chilli, cumin, coriander seed, tamarind paste, brown sugar, sugar and salt were purchased from Tesco, Section 13, Shah Alam. Analytical grade chemicals and standards used were purchased from Merck Sdn. Bhd., Selangor, Malaysia.

\subsection{Preparation of meat floss}

The percentage of beef meat in cassava floss was substituted with cassava leaves $(25 \%, 50 \% 75 \%$ and $100 \%$ ) and $100 \%$ beef in the formulation was used as control. Full formulation of meat floss is listed in Table 1. Cassava leaves were prepared firstly by cleaning it through running water to remove dust and dirt and then lightly pounded. The leaves were boiled for 30 mins to soften the texture and to ensure the removal of cyanide content. After cooling to room temperature for about 15 minutes, the leaves were cut into a smaller size $(1 \mathrm{~cm}$ length). Similarly, meat was washed and boiled for 20 minutes and shredded into floss-like texture after cooling. Other ingredients such as cumin, coriander seed, onion, garlic, ginger, galangal, dried chilly were blended and then sautéed until its colour turned light-brown. After that, brown sugar, sugar, salt, tamarind juice and coconut milk were added in and stirred well into the mixture. Shredded meat and/or cassava leaves were added and the mixture was further cooked until it becomes dry. The floss sample prepared was left aside to cool and then stored in cleaned polypropylene rigid plastic container at room temperature.

Table 1 Formulation of meat floss incorporated with cassava leaves

\begin{tabular}{|c|c|c|c|c|c|}
\hline & Control & F1 & F2 & F3 & F4 \\
\hline Meat (g) & $\begin{array}{c}152 \\
(100 \%)\end{array}$ & 114 & 76 & 38 & 0 \\
\hline Cassava leaves (g) & 0 & $\begin{array}{c}38 \\
(25 \%)\end{array}$ & $\begin{array}{c}76 \\
(50 \%)\end{array}$ & $\begin{array}{c}114 \\
(75 \%)\end{array}$ & $\begin{array}{c}152 \\
(100 \%)\end{array}$ \\
\hline Sauté ingredients (g) & \multicolumn{5}{|c|}{464} \\
\hline Brown sugar $(\mathrm{g})$ & \multicolumn{5}{|c|}{40} \\
\hline Sugar $(g)$ & \multicolumn{5}{|c|}{40} \\
\hline Salt (g) & \multicolumn{5}{|c|}{16} \\
\hline Tamarind juice $(\mathrm{g})$ & \multicolumn{5}{|c|}{48} \\
\hline Palm oil $(\mathrm{g})$ & \multicolumn{5}{|c|}{48} \\
\hline Coconut milk (g) & \multicolumn{5}{|c|}{48} \\
\hline
\end{tabular}

\subsection{Determination of protein, fiber and peroxide value}

Crude protein and fiber content were determined using macro-Kjeldahl method as described by AOAC (1995) [15]. Peroxide value was determined according to the method described by AOCS (1996) [16].

\subsection{Determination of Thiobarbituric acid}

Ten grams of sample was macerated with $50 \mathrm{ml}$ of distilled water for 2 minutes and washed into distillation flask with $47.5 \mathrm{ml}$ of water. An amount of $2.5 \mathrm{ml}, 4 \mathrm{M}$ acid $\mathrm{HCl}$ was added into the flask. Then the mixture was heated and the distillate was collected. Distillate $(5 \mathrm{ml})$ and TBA reagent $(5 \mathrm{ml})$ was pipetted into glass stoppered tube, shaken and heated in boiling water bath for 35 minutes and then cooled in water for 10 minutes. Blank was prepared by mixing $5 \mathrm{ml}$ distilled water and $5 \mathrm{ml}$ of TBA reagent. The absorbance was read against blank at $538 \mathrm{~nm}$ using spectrophotometer (UVA-160921, Helios- $\alpha$, England). TBARS value was calculated by multiplying A with 7.8 [17] and results were expressed as mg malondialdehyde/kg. 


\subsection{Sensory evaluation}

Sensory evaluation was conducted by 30 untrained panelists consisted of staff and students of Universiti Teknologi MARA, Shah Alam under laboratory conditions. Panelist preference was assessed using 9points hedonic scale with scale 1 corresponding to "extremely dislike" and 9 "extremely like". Attributes of texture, taste, color and overall acceptability of the floss was used. Water at room temperature was used as neutralizer between different samples.

\subsection{Statistical analysis}

Statistical analysis was conducted using IBM Statistical Package for the Social Science (SPSS) program (Version 19.0). Significant differences $(P \leq 0.05)$ between means were evaluated by one-way analysis of variance (ANOVA) and Duncan's new multiple range test. All analyses were performed in triplicate and expressed as mean \pm standard deviation.

\subsection{Crude protein and fiber content}

\section{Results and Discussion}

The protein and fibre content for each floss formulation is shown in Table 2. Protein content showed significant decrease $(P<0.05)$ with the increase of $C L$ substitution. The highest protein content was shown by control floss and the amount was decreased by $74 \%$ when beef was fully substituted with CL. A study [18] reported that protein content in commercial beef floss or 'serunding' ranges from $19.86 \%$ to $30.15 \%$; therefore, the protein in control floss in this study was within the reported range. Another study [19] showed lower protein content of $4.7 \mathrm{~g}$ to $6.9 \mathrm{~g}$ in cassava leave floss or 'empasak' (traditional Malaysia state Sarawak cuisine which uses cassava leaves as main ingredient).

Table 2 Protein and fibre content of meat floss incorporated with cassava leaves

\begin{tabular}{|c|c|c|c|c|c|}
\hline Sample & Control & $25 \%$ CL & $50 \%$ CL & $75 \%$ CL & $100 \%$ CL \\
\hline $\begin{array}{c}\text { Protein } \\
(\mathrm{g} / 100 \mathrm{~g})\end{array}$ & $28.99 \pm 0.27^{\mathrm{a}}$ & $19.47 \pm 0.16^{\mathrm{b}}$ & $15.42 \pm 0.24^{\mathrm{c}}$ & $11.60 \pm 0.44^{\mathrm{d}}$ & $7.57 \pm 0.14^{\mathrm{e}}$ \\
\hline $\begin{array}{c}\text { Fibre } \\
(\mathrm{g} / 100 \mathrm{~g})\end{array}$ & $2.27 \pm 0.11^{\mathrm{d}}$ & $2.49 \pm 0.04^{\mathrm{c}}$ & $2.59 \pm 0.08^{\mathrm{c}}$ & $3.49 \pm 0.07^{\mathrm{b}}$ & $4.37 \pm 0.07^{\mathrm{a}}$ \\
\hline
\end{tabular}

(Different letters of the same row indicate significant difference at $\mathrm{p}<0.05$ between samples)

$\mathrm{CL}$ is known for having considerable amount of fibre content, therefore its addition is expected to increase the fibre present in the product. Significant increase $(P<0.05)$ was observed in this study with the increase of CL; however, no significant difference $(P>0.05)$ was observed between $25 \%$ and $50 \% \mathrm{CL}$ substituted floss. The amount of fibre in $100 \% \mathrm{CL}$ floss was found to be twice of that in control sample. The dietary fibre content of 0.5 to $10 \mathrm{~g}$ dry matter in raw CL was reported by [20].

\subsection{Acceptability of cassava floss}

The result of sensory evaluation on cassava leave floss is shown in Fig. 1. For texture attribute, no significant difference $(P>0.05)$ was observed between control, 25\%, and 100\% CL floss. This indicates that panellists cannot differentiate between $100 \%$ beef and $100 \%$ CL floss since both beef and CL were well blended with other ingredients and showed no obvious difference in terms of texture. Similar result was observed for taste attribute. No significant difference $(P>0.05)$ obtained for control, $25 \%$ and $100 \% \mathrm{CL}$ also was significantly higher $(P<0.05)$ than $50 \%$ and $75 \%$ CL substituted floss. This shows that taste of $100 \%$ CL floss was well accepted by panellists similar to $100 \%$ beef floss.

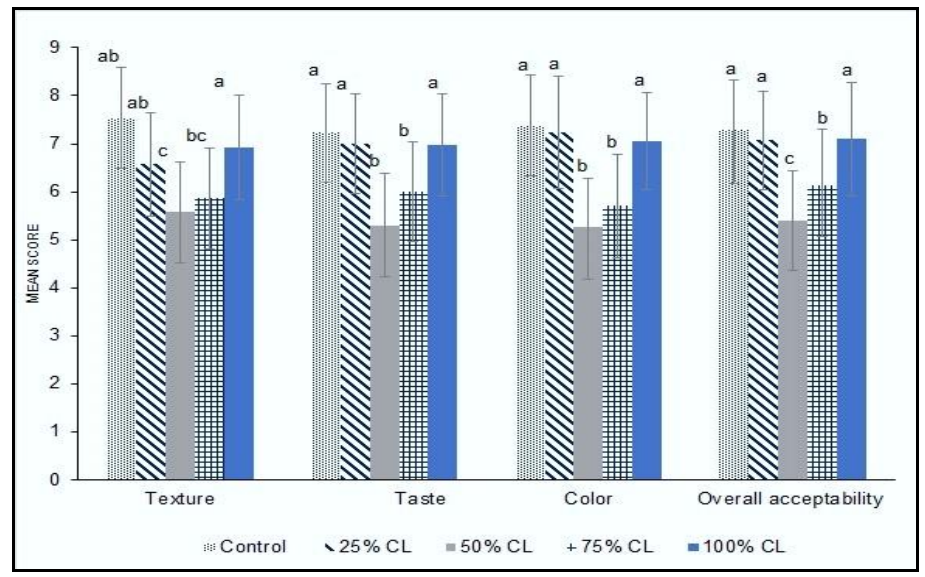

Fig.1 Acceptability of meat floss incorporated with cassava leaves

(Different letters over chart of the same sensory attribute are statistically different at $P<0.05$ ) 
Colour is an important parameter in acceptability of a product by consumer. In this study, colour acceptability of control floss showed no significant difference ( $\mathrm{p}>0.05)$ with $25 \%$ and $50 \%$ CL but showed significant decrease $(\mathrm{p}<0.05)$ with further increase in CL substitution. The panellists also commented on the darker colour of floss having higher CL. The green colour of CL became darker during cooking as compared to beef. For overall acceptability attribute, similar result with taste and colour attributes was obtained. Again, this clearly showed that full substitution of cassava leaves in meat floss was well accepted by panellists. This means that $100 \%$ CL or vegetable-based 'serunding' showed good potential for commercialization and its hedonic score of above 7 points make it's a promising product.

\subsection{Lipid oxidation during storage}

Primary oxidation of floss which indicates initial stage of oxidation in fats and oils was determined by measuring peroxide value (PV). Fig. 2 shows PV obtained during storage of 84 days. The curve of lipid oxidation showed similar trend in which drastic increase in PV was observed from day 0 to day 42 followed by gradual decrease which indicates its undergoing secondary oxidation. Similar PV trend was observed by [21] on dehydrated shredded meat products. Control floss showed higher PV due to the higher fat content in beef meat hence making it more susceptible to lipid oxidation. Lipid content reported in CL was in range of 3.5 to 7.3 [7], [6], [8]. A study by [22] showed that PV for fish beef floss at day 1 was $4.2 \mathrm{mEq} \mathrm{O}_{2} / \mathrm{kg}$ which was higher than $\mathrm{PV}$ of control floss at day $0(0.98 \mathrm{mEq} \mathrm{O} / \mathrm{kg})$ obtained in this study.

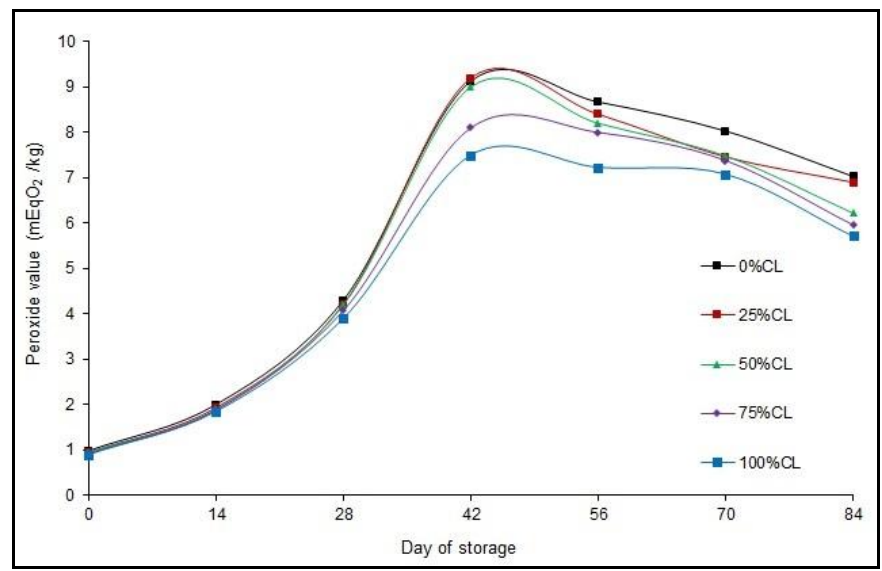

Fig. 2 Peroxide value of meat floss incorporated with cassava leaves during storage

A suggested limit of PV for quality and acceptability for human consumption is $8 \mathrm{mEq} / \mathrm{kg}$ [23]. Therefore based on this limit, floss of control, 25\%, 50\% and 75\% CL formulations have PV exceeding the quality limit at day 31, 32, 41 and 56 respectively. While fully substituted floss (100\% CL) was below the limit throughout the storage. This indicates that the vegetable-based floss is stable and has longer shelf life.

The secondary oxidation showed by TBARS value of floss during storage is presented in Fig. 3. A gradual increase in TBARS value was observed for all floss formulations during storage and the values were slightly lower with the increase amount of CL substituted in the floss. TBARS value of more than $1.5 \mathrm{mg} / \mathrm{kg}$ is usually associated with rancid flavour or odour that can be detected by sensory panellists based on off-odour perception [24], [25].

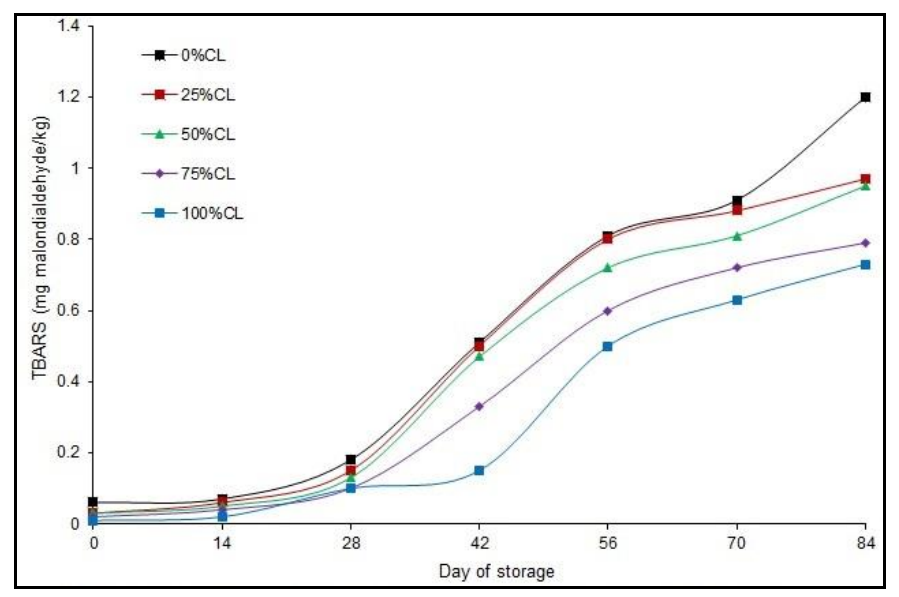

Fig. 3 TBARS value of meat floss incorporated with cassava leaves during storage 
At the end of storage day 84, all formulations showed TBARS value below the limit, which shows that all formulations will not develop the rancidity flavour and off-odour during storage. Some of the factors that contribute to the increase in TBARS during storage are inappropriate storage condition, action of light and oxygen content [21].

\section{Conclusion}

This study showed the potential of cassava leaves substitution with meat-based product with minimal effect on consumer acceptability. Increase in fiber content and higher stability towards lipid oxidation provides health beneficial and longer shelf life of the product. In famine stricken countries, where meat protein is scarce and costly, the utilization of CL as available cheap protein source in food products is a valuable advantage. Further study into application of CL in meat-based products should be encouraged in order to diversify usage of this underutilized vegetable.

\section{Acknowledgements}

The authors would like to thank Ministry of Higher Education Malaysia for providing MyBrain15 scholarship to Siti Sarah Jamil and also to laboratory staffs of Faculty of Applied Sciences UiTM Selangor and Faculty of Hotel and Tourism, UiTM Pulau Pinang for assistance and facilities provided. Special thanks to Arnieyantie for her guidance in the initial product formulation stage.

\section{References}

[1] FAO. (2012). Economic and social development department. In FAO statistical yearbook 2012.

[2] J. Berman, Zhu, C., Perez-Massot, E., Arj_o, G., Zorrilla-L_opez, U., Masip, G., et al. (2013). Can the world afford to ignore biotechnology solutions that address food insecurity? Plant Molecular Biology, 1-15.

[3] A.F. Awoyinka, Abegunde, V. O., \& Adewusi, S. R. A. (1995). Nutrient content of young cassava leaves and assessment of their acceptance as a green vegetable in Nigeria. Plant Foods for Human Nutrition, 47, 21-28.

[4] C. Wobeto, Corrêa, A. D., Abreu, C. M. P., Santos, C. D. and Abreu, J. R. (2006). Nutrients in the cassava (Manihot esculenta Crantz) leaf meal at three ages of the plant. Food Science and Technology, 26(4), 865-869.

[5] G.B. Oguntimein (1988). Processing cassava for animal feed. In L. R. S. K. Hahn, \& G. N. Egbunike (Eds.), Potential of cassava as livestock feed in Africa. IITA/ILCA/University of Ibadan.

[6] G. Ravindran \& Ravindran, V. (1988). Changes in the nutritional composition of cassava (Manihot esculenta Crantz) leaves during maturity. Food Chemistry, 27, 299-309.

[7] A.U. Achidi, Ajayi, O. A., Maziya-Dixon, B., \& Bokanga, M. (2008). The effect of processing on the nutrient content of cassava (Manihot esculenta Crantz) leaves. Journal of Food Processing and Preservation, 32, 486-502.

[8] P.A. Lancaster \& Brooks, J. E. (1983). Cassava leaves as human food. Economic Botany, 37, $331-348$.

[9] F.S. Camara \& Madruga, M. S. (2001). Cyanic acid, phytic acid, total tannin and aflatoxin contents of a Brazilian (natal) multimistura preparation. 14, 33-36.

[10] E.M. Aregheore (2012). Nutritive value and inherent anti-nutritive factors in four indigenous edible leafy vegetables in human nutrition in Nigeria: a Review. Journal of Food Resource Science, 1-14.

[11] S. Latif \& Muller, J. (2014). Cassava e how to explore the "all sufficient". Rural, 21, S., 30-31.

[12] G.J. Scott, Rosegrant, M. W., \& Ringler, C. (2000). Roots and tubers for the 21 st century trends, projections, and policy options (pp.1-64)

[13] N. Nassar \& Ortiz, R. (2010) Breeding cassava to feed the poor. Scientific American, May 2010 (www.ScientificAmerican.com)

[14] E. Nurulnahar (2013) Personal Communication. Research Officer, Agronomi dan Sistem Pengeluaran, Pusat Penyelidikan Padi dan Tanaman Industri, MARDI, Serdang (3rd Sept 2013).

[15] AOAC International (1995) Official methods of analysis, 15 ${ }^{\text {th }}$ edn.Method (981.10) (Macro Kjeldahl method), AOAC International,Gaithersbury,MD.

[16] AOCS (1996). Official Method Cd 8b-90 Peroxide value (acetic acid - isooctane method). In Official methods and recommended practices of the American oil chemists' society. Champaign, IL: AOCS Press.

[17] J.N. Martin, Brooks, J. C, Brooks,T. A, J. D, Legako, S. P, Starkey, M. F, \& Miller, M. F. (2013). Storage length,storage temperature, and lean formulation influence the shelf life and stability of traditionally packaged ground beef. Journal Meat Science (95),495-502)

[18] N. Huda, Fatma, Y., Fazillah, A. \& Adzitey, F. (2012). Chemical composition, colour and sensory characteristics of commercial 'serunding' (shredded meat) in Malaysia. Pakistan Journal of Nutrition, 11(1), 1-4.

[19] A.H. Arnieyantie, Rafidah Aida, R., Fadhlina, M., Norfezah, M. N., Nurul Huda, H., \& Anderson, N. (2012). Cassava (Manihot esculenta Crantz) leave floss a potential protein source. In UMT $11^{\text {th }}$ International Symposium on Sustainability Science and Management. 9-11 July, 2013, Terengganu, Malaysia.

[20] A. Montagnac, Davis, R. and Tanumihardjo, A. (2009). Nutritional Value of Cassava for Use as a Staple Food and Recent Advances for Improvement. Comprehensive Reviews in Food Science and Food Safety, 8(3), 181-194.

[21] O.O Ogunsola \& Omojola, A. B. (2008). Nutritional evaluation of a dehydrated shredded meat product, (Danbunama). Pakistan Journal of Nutrition, 7(4), 554-556.

[22] N.D. Eko, Ratna, I. \& Nazulia, Y. (2011). The shelf-life of seasoned fish meat floss (abon ikan) made from red tilapia (Oreochromis niloticus Trewavas) processed by different frying methods. Jurnal Saintek Perikanan, 6(1), 6-12.

[23] G. Boran, Karacam, H. and Boran, M. (2006).Changes in the quality of fish oils due to storage temperature and time. Food Chemistry, 6, 693-698.

[24] J.H. Comoze \& Green, G.E. (1981) Relationship between TBA number and inexperienced panelist assessment of oxidized flavour in cooked beef. Journal of Food Science, 47, 52-54.

[25] S. Dwivedi, Vasavada, M.N. \& Conforth, D. (2006) Evaluation of antioxidant effects and sensory attributes of chinese 5-spice ingredients in cooked ground beef. Journal of Food Science, 71(1), 12-17. 